\title{
Strategies to promote self-esteem, autonomy and self-care practices for people with chronic wounds
}

\author{
Estratégias de promoção da autoestima, autonomia \\ e autocuidado das pessoas com feridas crônicas \\ Estrategias para promover la autoestima, autonomía \\ y autoatención de personas con heridas crónicas
}

\author{
Liarine Fernandes Bedin ${ }^{\mathrm{a}}$ \\ Josefine Busanellob \\ Graciela Dutra Sehnem ${ }^{c}$ \\ Fernanda Machado da Silva ${ }^{d}$ \\ Márcia Adriana Polle
}

D0l: $\quad$ http://dx.doi.org/10.1590/1983-

1447.2014.03.43581

\footnotetext{
Nurse. R1 of Integrated Multi-professional Residency in Health with Emphasis on Intensivism, of the Universidade Federal de Ciências da Saúde de Porto Alegre. Member of Group of Studies and Research in Nursing of the Western Border of Rio Grande do Sul (GEPEnf FORS), of the Universidade Federal do Pampa (UNIPAMPA). Porto Alegre, Rio Grande do Sul, Brazil.

${ }^{b}$ Nurse. PhD in Nursing. Adjunct Professor of the Nursing Programme at UNIPAMPA. Head of the GEPEnfFORS. Uruguaiana, Rio Grande do Sul, Brazil.

'Nurse. PhD in Nursing. Adjunct Professor of the Nursing Programme at UNIPAMPA. Researcher of the GEPEnfFORS. Uruguaiana, Rio Grande do Sul, Brazil.

d Nurse. Master's in Nursing. Assistant Professor of the Nursing Programme at UNIPAMPA. Researcher of the GEPEnf FORS. Uruguaiana, Rio Grande do Sul, Brazil.

e Nurse. Master's in Nursing. Assistant Professor of the Nursing Programme at UNIPAMPA. Researcher of the GEPEnf FORS. Uruguaiana, Rio Grande do Sul, Brazil.
}

\begin{abstract}
This is a qualitative study of an exploratory nature that aims to identify the strategies used by nurses in primary care, in situations involving nursing care, to promote self-esteem, autonomy and self-care practices for people with chronic wounds. The study included eight nurses. Data were collected by means of a focus group in July 2012. The thematic analysis technique was used to identify the following categories: Nursing care from the perspective of comprehensiveness; Recovering support networks: family and social movements; Multidisciplinary work; Autonomy and nurses. It was concluded that the presented strategies value, above all, the social environment of these individuals, the family, religion and the nurse's approximation to the realities of people with chronic wounds. Descriptors: Nursing care. Primary health care. Nursing. Wound healing.
\end{abstract}

\section{RESUMO}

Trata-se de um estudo qualitativo de caráter exploratório, com o objetivo de identificar as estratégias utilizadas por enfermeiros da atenção básica, nas situações que envolvem o cuidado de enfermagem para promover a autoestima, a autonomia e 0 autocuidado das pessoas com feridas crônicas. Participaram do estudo oito enfermeiros. A coleta de dados foi realizada por meio de grupo focal, realizado em julho de 2012. Para análise dos dados, utilizou-se a técnica de Análise Temática, que permitiu a identificação das categorias: Cuidado de enfermagem na perspectiva da integralidade; Resgate das redes de apoio: família e movimento sociais; Trabalho multiprofissional; e Autonomia do Enfermeiro. Concluiu-se que as estratégias apresentadas valorizam, principalmente, 0 ambiente social desses indivíduos, a família, a religião e a aproximação do enfermeiro com a realidade de vida das pessoas com feridas crônicas. Descritores: Cuidados de enfermagem. Atenção primária à saúde. Enfermagem. Cicatrização.

\section{RESUMEN}

Se trata de un estudio cualitativo de carácter exploratorio, con el objetivo de identificar las estrategias utilizadas por las enfermeras de atención primaria, en las situaciones que implican los cuidados de enfermería para promover la autoestima, la autonomía y el autocuidado para las personas con heridas crónicas. El estudio incluyó a ocho enfermeras. La recolección de datos se realizó a través del grupo focal realizado en julio de 2012. Para el análisis de datos, se utilizó la técnica de análisis temático que permitió la identificación de las categorías: Cuidado de enfermería a la vista de la exhaustividad; Rescate de las redes de apoyo: la familia y el movimiento social; Trabajo multidisciplinario; La autonomía y la enfermera. Llegamos a la conclusión de que las estrategias presentadas valor, sobre todo el entorno social de estas personas, la familia, la religión y el enfoque de la enfermera con la realidad de la vida de las personas con heridas crónicas.

Descriptores: Atención de enfermera. Atención primaria de salud. Enfermería. Cicatrización de heridas. 


\section{口INTRODUCTION}

The main characteristic of chronic wounds is prolonged healing, recurrent infections and complications associated to the base disease. The etiology of these wounds is chiefly vascular problems, with a greater incidence of arterial and venous ulcers, neuropathic ulcers and pressure ulcers ${ }^{(1)}$.

Chronic wounds cause a series of changes in the patient's life, such as social isolation, the need to adapt to daily dressing sessions, changes in physical activity, food abstinences, continuous use of medication and, above all, disturbances to self-image. These changes cause discouragement and the incapacity for self-care, activities of everyday life and social conviviality ${ }^{(1)}$.

Consequently, in addition to nursing interventions to prevent complications and restore tissue lesions, it is necessary to identify strategies to confront these changes ${ }^{(1)}$, based on promoting self-esteem, autonomy and self-care.

Self-esteem is defined as a fundamental human need in which individuals learn to believe in their own ideas and in themselves, thus positively acknowledging their own image ${ }^{(2)}$. Autonomy is the individual's capacity to make choices in a critical and sensible manner ${ }^{(3)}$. Selfcare is the critical awareness of an individual in relation to health and well-being, which is translated into the capacity to meet one's own needs, even in situations of disease ${ }^{(4)}$.

Scientific evidence shows that adherence to treatment and some changes to everyday habits are possible from the moment individuals develop self-esteem, autonomy and self-care ${ }^{(5,6)}$. In this sense, the question is: Which strategies can nurses use to promote self-esteem, autonomy and self-care practices for people with chronic wounds?

Research is required to identify strategies that can be added to the nursing care plan and that stimulate the capacity of people with chronic wounds to manage their situation and become the protagonists of promoting their own health ${ }^{(7)}$. This shortage of research therefore justifies the relevance of this study, which has the aim of identifying strategies adopted by nurses of primary care to promote self-esteem, autonomy and self-care practices for people with chronic wounds.

\section{METHOD}

This qualitative study of an exploratory nature ${ }^{(8)}$, is based on data of the study titled'Percepção de Enfermeiros acerca dos Cuidados de Enfermagem a Indivíduos Portado- res de Feridas: Perspectiva da Atenção Básica do Município de Uruguaian' (Perception of Nurses on Nursing Care for Individuals with Wounds: Perceptive of Primary Care in the Municipality of Uruguaiana), that was conducted during the course 'Enhanced Nursing Care for Individuals with Wounds'.

The investigative scenario was Primary Care Units (UBS) in a municipality of southern Brazil, in neighbourhoods on the outskirts and in the centre of the city, that offer healthcare service eight hours a day based on the local demand of age groups and schedules. Study participants were eight nurses who practiced in these healthcare services. These units do not observe the family health strategy policy, which is reflected in the services provided by nurses that is restricted to dressing lesions, especially for people with chronic wounds.

Sample composition criteria were: participate in an extended training course for wound care; and currently practicing at the UBS. Criteria for exclusion were to be on leave during data collection; and not participate in at least one third of the extended training course activities.

Data were collected using the focal group technique, in July 2012, starting with a debate among nurses on the following questions: Which strategies are used to promote self-esteem, autonomy and self-care practices for people with chronic wounds? What is the basis to define strategies? What are the difficulties to implement these strategies?

The focal group attended three meetings, conducted in a pleasant and comfortable environment, for no longer than two hours. All meetings were conducted by a mediator and a non-participating observer who helped record the debate in MP3 format. A subject guide was used, containing the objectives of the focal encounters and the questions asked to promote debate ${ }^{(9)}$.

All the discussions were transcribed and submitted to thematic analysis, considering the following stages: pre-analysis, exploration of material and treatment and interpretation of results ${ }^{(8)}$. This study was approved by the UNIPAMPA Research Ethics Committee, on October 11, 2011, number 034/2011. All ethical perspectives were observed, and nurses formalized their participation by signing an informed consent statement.

\section{RESULTS AND DISCUSSION}

Results are based on four thematic categories: Nursing care from the perspective of comprehensiveness; Recovering support networks: family and social movements; Multidisciplinary work; Autonomy and nurses. 


\section{Nursing Care from the perspective of comprehensiveness}

Promoting self-esteem, autonomy and self-care practices for people with chronic wounds depends on care practices that meet all human needs, without focusing solely on the wound itself. Nurses emphasize the evaluation of the clinical situation, social environment and psychological condition of each individual based on the history of life, health and disease.

When we provide care, first, we check the signs [...]I'll analyse the wound. But, we have to analyse the whole, his entire situation [...]also, we must know where this person lives. (E5)

I have one reality here, which is chronic, and it involves everything. And I have to know everything that goes beyond the wound so he can have self-esteem, autonomy and engage in self-care. (E1)

The perspectives discussed by the nurses reveal there is a new paradigm of care for people with chronic wounds that reaches beyond the assistance model that merely focuses on the tissue lesion, rather than the context in which the individual is inserted ${ }^{(10)}$. The clinical evaluation of individuals and the lesion, defining the clinical plan, records and prognosis of the disease, observe some important aspects of the care methodology adopted by nurses to assist people with chronic wounds (11).

This perspective must be present in the healthcare work process to produce nursing care that is centred on users, including, in addition to the disease, the subject in his or her collective context. According to the comprehensiveness of care, the object, means and ends of care, other than curing and alleviating pain, aim to develop autonomy in individuals so they can accept their problems and concrete living conditions ${ }^{(11)}$.

It is essential to consider psychological, social and cultural aspects that are directly connected to the development of this chronic condition. People with chronic wounds must face serious changes in their way of life that can lead to low self-esteem, reduced autonomy and selfcare deficits ${ }^{(12-13)}$.

Emotional changes, especially non-acceptance of the lesion and chronic situation, are presented as the main difficulties faced by nurses when promoting self-esteem, autonomy and self-care. In these cases, nursing care must meet psychosocial needs based on valuing and stimulating people with chronic wounds.

Another side is acceptance. He doesn't accept it. He becomes dependent, gets depressed, he doesn't accept it. He doesn't want to help himself. (E2)

It's precisely that emotional side that's involved [...]W We have to attend to, not only the wounds, but the other issues that lead to several possibilities of speaking and conducting situations. (E3)

A chronic condition results in losses and dysfunctions that affect the daily lives of sufferers, leading to psychological strain and suffering. The chronic wound directly affects the psychosocial condition of individuals, resulting in loss of work roles, financial productivity, social competence and relationships and emotional processes with family members and friends ${ }^{(7)}$.

Promoting self-esteem, autonomy and self-care practices in people with chronic wounds is not an easy task. It is necessary to know the individual, the disease, and socioeconomic, emotional and family conditions ${ }^{(14)}$. Consequently, it is important to consider all aspects, visible to the body. This prevents the professional-patient relationship from becoming too technical, cold and distant, and leads to satisfactory results in the process of recovering self-esteem, autonomy and self-care ${ }^{(15)}$.

\section{Recovering support networks: family and social groups}

Inclusion of the family and social groups in care practices is a strategy to promote self-esteem, autonomy and self-care. The nurses discussed difficulties in promoting participation and involvement of support networks in the care processes of these individuals.

Some authors $(7,10,12,16)$ emphasize the need to strengthen and establish support networks that include social actors in the lives of people with chronic wounds. These support networks are very important to ensure commitment and inclusion of individuals in the planning of their care, and provide the necessary support for self-esteem, autonomy and self-care.

Involving and preparing family members are essential strategies to build an emotional support basis. Sufferers may not be internally motivated to face daily difficulties that accompany the presence of wounds. However, from the moment they perceive that family members are also 
willing to face this situation, they tend to show self-esteem and autonomy, and conditions for self-care.

\section{[...] Family members also have to try to find a solution. Give support, be present and motivate. That also helps, with self-esteem and autonomy. (E5)}

The higher the number of family members involved and helping him, the better. But we also need to prepare them to encourage self-care. (E6)

Family members must also help people with chronic wounds to identify ways to confront their physical and mental suffering ${ }^{(12)}$. It is also believed that families become important allies for people with chronic wounds to receive participative care ${ }^{(6)}$. The family is therefore considered a realm in which the subject of care resides. Consequently, it is important to know the health problems and needs according to the physical, financial and social context of patients and their families ${ }^{(6)}$.

In relation to this aspect, nurses extended the discussion on awareness and preparation of the family to participate in providing care and motivating patients; they mentioned the importance of collective approaches, with the participation of family members when patients receive care at the health unit, in order to share difficulties, fears and doubts. The need for individual approaches, however, was not discarded, as some family members can try to control the situation and exhaust any possibility of self-esteem, autonomy and self-care.

I can work with the family. I listen to the family and the patient, answer any questions. And that is very positive, as he is sharing the problems. His self-esteem increases. (E4)

But, in some situations we have to work individually, especially when families want all the attention. (E3)

We can perfectly have two moments [...]we speak separately. Sometimes, the family smothers the patient. They strip the patient of any chance of deciding or doing anything. That is bad. (E1)

Chronic conditions create several demands for the family, which is often not prepared to understand the situation ${ }^{(12)}$. Clear and elucidating information provided by nurses is important to obtain an understanding of the objective and meaning of care, and even of possible restrictions. This can help encourage patients to adhere to treatment. However, preventing complications must be approached by professionals collectively within the family in the home, considering that the family plays an important role in adherence to treatment and encouraging self-care ${ }^{(6)}$.

A study conducted to evaluate the mental health of people with chronic wounds revealed that the emotional stability of these individuals is related to treatment and daily difficulties. Moreover, suffering of people with chronic wounds chiefly depends on the level of family commitment ${ }^{(17)}$.

The participation of people with chronic wounds in social groups, which also constitute a support network, especially religious movements and community associations, was also a strategy discussed by nurses. It is important to encourage participation in this type of movement, considering that behaviour of these individuals is profoundly influenced by belief and values learned within the social context.

Having a social life is very important. Self- esteem also depends on that. (E2)

That's another alternative for him. When he goes to church, he finds himself there. And comes back feeling much better, it doesn't matter which church he attends. (E7)

[...] I ask him if he follows any religion, participates in any community activity. They can't exclude themselves from social life. (E6)

This same perspective was identified in a study on the quality of life of people with chronic wounds in their lower limbs. These individuals found several difficulties that mostly emerge from the need to tend to the wound on a daily basis and recurrent hospitalization, during which patients must abandon their work and social activities ${ }^{(1)}$.

One of the main problems confronted by people with chronic wounds is prolonged treatment. This process can trigger loss of self-esteem resulting from the incapacities the lesion causes, such as pain, sleep deficits, inaptitude for work, shame and embarrassment when socializing ${ }^{(17)}$.

The presence of chronic wounds can change people physically and psychosocially; hence the importance of social and cultural involvement ${ }^{(16)}$. Self-esteem, autonomy and self-care are strongly influenced by beliefs that oftentimes interfere with the willingness and confidence of these individuals to execute a specific action and persist in that action ${ }^{(7)}$. Furthermore, faith and interaction with the community give people hope, create expectations and optimism, and provide emotional balance ${ }^{(12)}$. 


\section{Multidisciplinary work}

The nurses also discussed participation of other healthcare professionals in the promotion of self-esteem, autonomy and self-care practices for people with chronic wounds based on the implementation of aligned and coherent care actions. Joint planning is important to reach treatment and recovery objectives.

The patient needs a multidisciplinary team. We, nutritionists, doctor, psychologist, all of us will help find a way for the patient to maintain their self-esteem and engage in self-care practices. (E8)

The professionals have to work together, following the same lines. Discuss, plan and find the best solutions. (E4)

Healthcare professionals must promote the individual's capacity to plan, define goals and make choices on his or her health situation and disease. This perspective should permeate the planning of care to ensure patient confidence in relation to the provided care, thus establishing a link between the population and the service.

Patients have a tendency to become more fragile, especially due to symptoms of the disease that cause pain, odours and secretion. Emotional support must be a priority, to favour the capacity to perceive signs and symptoms and make decisions to solve problems caused by the chronic situation ${ }^{(10)}$.

Promoting the quality of life of people with chronic wounds is a huge challenge for healthcare professionals. Many times, professionals who provide care for people with wounds do not perceive the extent to which the wound can interfere with the patient's way of life. Consequently, care must be extensive and help patients find strategies to occupy their time and thoughts with activities that can create self-confidence, such as arts and leisure or situations that can add hope to treatment ${ }^{(18)}$.

The chronic condition requires that healthcare professionals create strategies that promote and value people with chronic wounds, according to their responsibilities and functions, when controlling their pathologies. Evidence shows that adherence to treatment, change of habits and the development of self-care skills are the results of approximation and the effective realization of interpersonal relationships ${ }^{(6)}$.

Nurses can conduct their care practices in a differentiated way. Approximations between nurses and patients favour verbalization of symptoms of the base disease and tissue lesions, other aspects of everyday life, problems, afflictions and frustrations related to care and treatment of chronic wounds. Allowing room for reciprocity between nurses and individuals encourages the creation of strategies that favour self-esteem, autonomy and self-care. For this reason, healthcare practices can no longer be based on a fragmented view. Although nurses are chiefly responsible for accompanying these patients, other healthcare professionals are also important to ensure the quality of care ${ }^{(12,16)}$.

\section{Autonomy and nurses}

Nurses' autonomy in the process of providing care for people with chronic wounds was also discussed. The greater the autonomy of nurses in their work context, the higher the possibility of positively acting to promote autonomy, self-esteem and self-care in patients.

I have to have professional autonomy and try to help him with my knowledge. (E3)

During the nursing consultations, the nurse has to have autonomy to guide, stimulate, try to understand the patient's context. This is all part of the nurse's competency. (E6)

For me to be able to encourage self-esteem and self-care, I have to show my autonomy. I have to motivate him, show him the way and not impose anything. (E4)

Although research on wound care and the experience of people with chronic wounds is abundant in the scientific productions of nursing, in many contexts of care, it is not clear that the responsibility for treating and preventing wounds is being attributed to nurses. This perspective does not actually agree with the activities conducted at primary care units, in which nurses predominately provide care for these patients ${ }^{(5,19)}$.

It is important for these professionals to develop the skills they need to provide relief for patients and their wounds, prescribe the best treatment, and guide and supervise nursing units during topic therapy. Nurses must perceive that these competencies are part of their daily routines ${ }^{(19)}$.

Resolvability and quality of nursing care depends on the autonomy of nurses to define the care methodology. The participants discussed the possibility of nurses implementing a better way of approaching patients, involving them and triggering interest in self-care by promoting autonomy and self-esteem. 
Try to make him jointly responsible for treatment, and to also have autonomy. (E5)

Teach him to practice self-care and depending on what you say to him, he'll feel valued. All that helps to improve his self-esteem. (E8)

The autonomy of nurses should not be associated with an arbitrary position, placing other professionals of the nursing team, their patients and family members in a submissive situation without considering the possibility of sharing decision-making, and fomenting interest and involvement of these subjects in care practices. This perspective is also revealed in a study that showed that non-participation of patients and even non-adherence to treatment usually occurs when nurses do not actively participate in decisions of the healthcare unit, and when nurses do not show autonomy when defining their activities in the context of care. The difficulties faced by nurses when trying to achieve or restore autonomy are associated with a lack of stimulus in the exercise of power ${ }^{(19)}$.

This debate clearly shows that nurses are interested in expanding their knowledge on treatment for people with wounds. Wound care is a specialization that demands multiple levels of knowledge and versatility in the practice of nurses, who must have the autonomy to implement comprehensive care for this population ${ }^{(19)}$.

\section{FINAL CONSIDERATIONS}

The strategies presented by nurses especially value the social environment of people with chronic wounds; and the work of multidisciplinary teams for care planning to be effective. In the scope of primary care, these strategies to promote self-esteem, autonomy and self-care practices can be strengthened, considering the possibility of nurses becoming more familiar with the lives and realities of these patients and their families.

It should be noted that the main limitation of this study is associated with the care methodology in the investigative scenario, which does not observe the family care strategy policy, in which care is mostly restricted to dressing wounds. This perspective minimizes strategies that can contribute to the promotion of autonomy, self-esteem and self-care practices in people with chronic wounds.

In this sense, this study verified the need for maintaining improvement actions for nurses and other members of the multidisciplinary team. In the scope of teaching, content or specific curricular components should be included to address the role of nurses and nursing when providing care for people with chronic wounds.

In the scope of universities, to which this study is related, this perspective has already been implemented, observing the importance of supporting future nurses to manage these situations in all contexts of care. Another aspect that should be emphasized is the importance of new studies that seek to identify new care possibilities and innovative technologies for people with chronic wounds.

\section{QREFERENCES}

1. Albuquerque RE, Alves EF. Análise da produção bibliográfica sobre qualidade de vida de portadores de feridas crônicas. Rev Saúde Pesqui. 2011;4(2):147-52.

2. Bedin LF. Promoção da Self-esteem, autonomy and self-care dos indivíduos com feridas crônicas: contribuições da enfermagem [monografia]. Uruguaiana (RS): Universidade Federal do Pampa; 2013.

3. Haeser LM, Büchele F, Brzozowski FS. Considerações sobre a autonomia e a promoção da saúde. Physis. 2012;22(2):605-20.

4. Taddeo PS, Gomes KWL, Caprara A, Gomes AMA, Oliveira GC, Moreira TMM. Acesso, prática educativa e empoderamento de pacientes com doenças crônicas. Ciênc Saúde Coletiva. 2012;17(11):2923-30.

5. Lara MO, Pereira Júnior AC, Pinto JSF, Vieira NF, Wichr P. Significado da ferida para portadores de úlceras crônicas. Cogitare Enferm. 2011;16(3):471-7.

6. Mendes EV. 0 cuidado das condições crônicas na atenção primária à saúde: 0 imperativo da consolidação da estratégia da saúde da família. Brasília: Organização Pan-Americana da Saúde; 2012.

7. Riegel B, Jaarsma T, Strömberg A. A Middle-range theory of self-care of chronic illness. Adv Nurs Sci. 2012;35(3):194-204.

8. Minayo MCS. 0 desafio do conhecimento: pesquisa qualitativa em saúde. São Paulo: Hucitec; 2010.

9. Busanello J, Lunardi Filho WD, Kerber NPC, Santos SSC, LunardiVL, Pohlmann FC. Grupo focal como técnica de coleta de dados. Cogitare Enferm. 2013;18(2):35864.

10. Rangel RF, Backes DS, Pimpão FD, Costenaro RGS, Martins ESR, Diefenbach GDF. Concepções de docentes de enfermagem sobre integralidade. Rev Rene. 2012;13(3):514-21.

11. Matumoto S, FortunaCM, Kawata LSK, Mishima SM, Pereira MJB. A prática clínica do enfermeiro na atenção básica: um processo em construção. Revista Latino-am Enfermagem. 2011;19(1).

12. Waidman MAP. 0 cotidiano do indivíduo com ferida crônica e sua saúde mental. Texto Contexto Enferm. 2011;20(4):691-9.

13. Geraldo MS. Processo de viver do portador com ferida crônica: atividades recreativas, sexuais, vida social e familiar. Saúde Coletiva. 2010;46(7):300-4.

14. Carneiro CM, Sousa FB, Gama FN. Tratamento de feridas: assistência de enfermagem nas unidades de atenção primária de saúde. Rev Enferm Integrada. 2010;3(2): 494-505.

15. Busanello J, Silva FM, Sehnem GD, Poll MA, Deus LML, Bohlke TS. Assistência de enfermagem a portadores de feridas: tecnologias de cuidado desenvolvidas na atenção primária. Rev Enferm UFSM. 2013;3(1):175-84.

16. Silva CT. Qualidade de vida: relato dos pacientes portadores de feridas submetidos ao tratamento de oxigenoterapia hiperbárica [dissertação]. Porto: Universidade do Porto; 2010. 
17. Waidman MAP, Rocha SC, Correa UL, Brischiliari A, Marcon SS. 0 cotidiano do indivíduo com ferida crônica e sua saúde mental. Texto Contexto Enferm. 2011;20(4):691-9.

18. Lara M0, Júnior ACP, Pinto JSF, Vieira NF, Wichr P. Significado da ferida para portadores de úlceras crônicas. Cogitare Enferm. 2011;16(3):471-7.

\section{Author's address:}

Josefine Busanello

Universidade Federal do Pampa - Curso de Enfermagem

BR 472, Km 592, Caixa Postal 118

97508-000, Uruguaiana, RS

E-mail: josefinebusanello@unipampa.edu.br
19. Ferreira AM, Bogamil DDD, Tormena PC. 0 enfermeiro e o tratamento de feridas: em busca da autonomia do cuidado. Arq Ciênc Saúde. 2008;15(3):105-9

20. Busanello J, Lunardi Filho WD, Kerber NPC, Lunardi VL, Santos SS. Participação da mulher no processo decisório no ciclo gravídico-puerperal: revisão integrativa do cuidado de enfermagem. Rev Gaúcha Enferm. 2011;32(4):807-14. 